\title{
PEMBENTUKAN DERIVATIF KATA BAHASA ARAB DALAM PERSPEKTIF MAZHAB KUFAH
}

\author{
Arifuddin \\ arifuddin@staff.uns.ac.id \\ Program Studi Sastra Arab \\ Fakultas Ilmu Budaya Universitas Sebelas Maret Surakarta
}

\begin{abstract}
The construction of word in Arabic language had been done by the process of derivation, by looking into this process, the lexicon of Arabic language can be reached and also it can be developed by the period. This research will investigate the construction of Arabic derivative word in the perspective of Kufah Scholar. The data in this research was divided into certain theories and facts of language collected from the primary and secondary references. The primary reference included the main opus work from the Kufah scholars, such as: Al-Farra', and also some works from Al-Anbari who had been collected and noted many opinions belong to Kufah scholar during the confrontation with the Basrah scholar. An amount of the research results and some works of contemporary Arabic Grammarians had been become the secondary reference of this research. This research had been concluded that the process of derivation in Arabic word in the Kufah Scholar had many variants of patterns and the high forms. This condition was caused by the data of language which had been recognized wider range of Basrah scholar. The opinion of Kufah Scholar about the root or radical had the strong basis in the development of contemporary of linguistics, especially in the Semitic Language.
\end{abstract}

Keywords: Derivation, Radical, the Pattern of language forms, Kuffah Scholar

$$
\begin{aligned}
& \text { ملخص } \\
& \text { صيغت الكلمات العربية بطرائق عديدة من أهما الاشتقاق ـ فمن خلاله برزت الكلمات أو المفردات الكثيرة }
\end{aligned}
$$

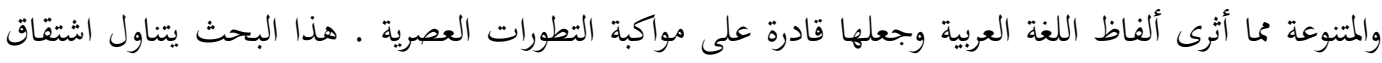

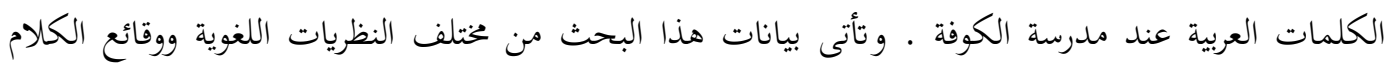

$$
\begin{aligned}
& \text { العربي التى سجلها المراجع الأولية والثانوية ـ تتمثل المراجع الأولية في كتب الأعلام الكوفيين مثل الكسائي والفراء }
\end{aligned}
$$

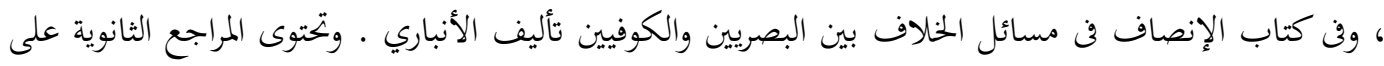

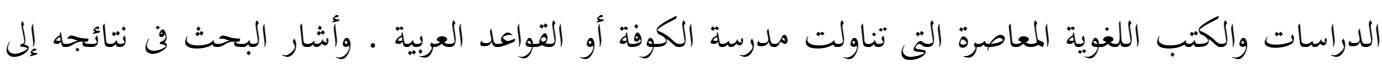

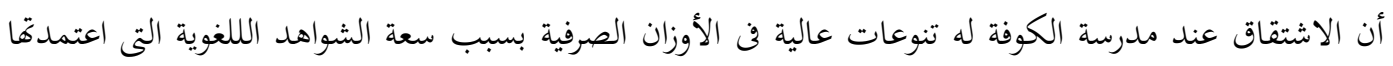

$$
\begin{aligned}
& \text { المدرسة فن دراستها اللغوية ، وأن رأيها عن المشتق منه أو مصدر الاشتقاق له سند قوي عند المات اللغوية المعاصرين } \\
& \text { خاصة في مجال اللغات السامية } \\
& \text { الكلمات الدليلية : الاشتقاق ، الجذر ، الأوزان ، مدرسة الكوفة . }
\end{aligned}
$$




\section{Pendahuluan}

Morfologi merupakan sub sistem ilmu linguistik yang menggeluti persoalan kata dan pembentukannya atau yang disebut proses morfologis. Proses morfologis ini merupakan suatu proses yang mengubah leksem atau satuan leksikal menjadi kata (Arifin, 2009: 9). Sebagai contoh, kata "makanan", "dimakan", "termakan" masing-masing terdiri atas dua bentuk bermakna yaitu -an, di-, ter- dengan makan. Bentuk-bentuk tersebut dapat berubah karena terjadi suatu proses. Kata makan dapat berubah menjadi makanan, dimakan, termakan karena masing-masing adanya penambahan -an, di-, dan terPerubahan bentuk atau struktur kata tersebut dapat pula diikuti oleh perubahan jenis atau makna kata. Seluk-beluk struktur kata serta pengaruhnya perubahanperubahan struktur kata terhadap golongan dan arti kata seperti di atas itulah yang dipelajari oleh bidang morfologi (Ramlan, 1983: 3).

Dalam bahasa Arab, proses morfologis dimulai dari apa yang disebut sebagai jidzr atau ashlun (radikal), yaitu inti kata yang mengandung makna inti dan menjadi dasar pembentukan kata (Al-Khuli, 1982: 236; Baalbaki, 1990: 416; Kridalaksana, 2009: 4). Kata radikal ini kemudian mengalami proses afiksasi atau pemberian imbuhan ( $\left.z \bar{a}^{\prime} i d a h\right)$ atau disebut pula morfem terikat yang ditambahkan dalam kata sehingga berubah tugas dan maknanya. Al-Khuli (1982: 8) menyebut imbuhan ini sebagai zawā'id dan Baalbaki (1990: 35) menyebutnya mūrfim muqayyad. Dari proses pembentukan ini muncul sejumlah kata turunan yang beragam baik jenis atau maknanya seperti kata kataba yang menurunkan kata kātibun, maktabun, kitābun, maktūbun dan yang lain. Proses pembentukan ini disebut sebagai proses derivasi atau isytiqāq dalam bahasa Arab, yaitu proses afiksasi penurunan kata atau unsur leksikal tertentu menjadi kata yang tidak sama atau unsur leksikal lain (Baalbaki, 1990: 143).

Sebagai tema utama morfologi, pembentukan derivatif kata dalam bahasa Arab melahirkan diskursus dan wacana kreatif dari para pakar gramatika bahasa Arab. Adu gagasan dan lempar ide tentang isu ini tidak jarang memunculkan sikap kontroversial sebagian pakar gramatika. Diantara pandangan yang dianggap kontroversi oleh sebagian besar pakar gramatika Arab pada masa klasik adalah pandangan atau mazhab Kufah.

Mazhab Kufah merupakan mazhab gramatika Arab yang lahir dan tumbuh di kota Kufah, Irak pada abad kedelapan Masehi atau kedua Hijriyah melalui pencetusnya Mu'ādz bin Muslim al-Harrā' (187 H./ 803 M.). (Al-Fadhlī, 1986: 45) Mazhab ini adalah mazhab kedua yang muncul dalam khazanah kajian linguistik Arab setelah sebelumnya muncul mazhab pertama, yaitu mazhab Bashrah pada abad ketujuh Masehi atau pertama Hijriyah dengan pencetusnya yaitu Abū al-Aswad ad-Du'āli (68 H./ 688M.) (Dhaif, 1992: 13) Sebagai mazhab yang lahir di bawah kejayaan kajian gramatika mazhab Bashrah, di awal permulaan perjalanannya mazhab Kufah banyak mengadopsi pendapat-pendapat mazhab Bashrah. Sampai akhirnya, muncul tokoh kunci independensi mazhab Kufah dari mazhab Bashrah yaitu Ali bin Hamzah Al-Kisā'î (189H./ 805M.) dan muridnya Yahya bin Ziyād al-Farrā' (207 H./ 822 M.) Berkat kontribusi kedua tokoh ini, mazhab Kufah mulai diakui sebagai mazhab yang independen dan lepas dari bayang-bayang senioritas mazhab Bashrah. Bahkan, alMakhzūmī (1955: 95) menyatakan bahwa kedua tokoh tersebut merupakan pencetus sesungguhnya mazhab Kufah.

Dalam catatan sejarah perjalanan ilmu gramatika Arab, mazhab Bashrah dan mazhab Kufah merupakan dua mesin penggerak yang telah berhasil mengantarkan ilmu gramatika Arab pada masa keemasaannya. Dialog, diskusi, dan perdebatan diantara keduanya telah meramaikan jagad wacana gramatika Arab, bahkan sampai berabad-abad setelahnya. Tidak berlebihan jika disampaikan bahwa rumusan kaidah dan teori gramatika Arab sampai sebelum era modern sangat ditentukan oleh perdebatan dan perselisihan antara kedua mazhab ini. Perselisihan pendapat di antara keduanya merupakan inti utama persoalan gramatika Arab. (Ath-Thawīl, 1984: 9)

Ada sejumlah alasan yang menempatkan mazhab Kufah memiliki kedekatan metodologis dengan kajian 
bahasa kotemporer, khususnya dalam kaitanya dengan metodologi deskriptif (alChammūz, 1997: 6-9), yaitu:

1. Proses penelitian yang dilakukan berjalan secara induktif dengan mengambil koleksi data lingual dari sumber otentik yaitu penutur Arab Baduwi yang masih memiliki sense lingual murni Arab. Mereka mendatangi kampung-kampung di pedalaman Jazirah Arab untuk menyimak data, mencatat, dan kemudian menganalisis fenomena lingual yang terdapat di dalamnya sehingga mampu didapat suatu konsep atau teori kebahasaan yang valid.

2. Memperluas cakupan landasan metodologis dalam penetapan suatu kaidah atau teori baik secara temporal, areal, ataupun personal. Mazhab Kufah bersedia menerima atau menvalidasi data kebahasaan yang datang dari berbagai latar lingual yang mencakup bacaan AlQuran yang $s y \bar{a} d z$ (menyimpang), puisi atau prosa yang tidak diketahui penuturnya, kata atau kosa kata yang menyimpang secara kaidah, atau kabilah dan komunitas yang diindikasikan telah hilang sense arabnya. Dengan demikian, dapat dinyatakan bahwa mazhab Kufah lebih menghargai suatu data lingual dengan ragam latarnya untuk kemudian dijadikan landasan pembentukan teori kebahasaan.

3. Mazhab Kufah menolak secara tegas praktek interpretasi, asumsi, prediksi, dan bentuk-bentuk pemaknaan bahasa yang tidak sesuai dengan bentuk lahiriah bahasa itu sendiri. Sikap ini adalah manifestasi nilai pemenuhan karakter dan ruh suatu bahasa.

4. Dalam hal analogi lingual, teori yang dirumuskan oleh mazhab Kufah mengakomodasi secara komprehensif ragam bentuk bahasa yang disimak tanpa berlebihan dalam menggunakan logika nalar dan pemaknaan bahasa secara artifisial.
Sejumlah alasan tersebut mengerahkan penulis untuk mengkaji persoalan pembentukan derivatif kata dalam perspektif mazhab Kufah. Artikel ini bertujuan untuk mendeskripsikan teori derivasi dan prosesnya dalam pembentukan kata berdasarkan kaidah yang telah disusun oleh mazhab Kufah. Perspektif mazhab Bashrah dalam hal ini juga akan disinggung secara singkat untuk memberikan pemahaman utuh tentang kronologi munculnya pandangan mazhab Kufah. Selain itu, pandangan pakar gramatikal Arab kontemporer juga akan dikemukakan untuk menunjukkan sejauh mana dampak pengaruh mazhab Kufah terhadap kajian gramatika Arab kontemporer.

\section{Metodologi}

Artikel ini merupakan bentuk kajian literatur gramatika Arab yang mendasarkan kajiannya terhadap informasi dan data yang ditemukan dalam sejumlah literatur sumber kajian. Setelah dilakukan penelusuran literatur berdasarkan bahanbahan yang relevan dengan merujuk kepada permasalahan yang diteliti, penelitian ini mengklasifikasi literatur kajiannya atas literatur primer dan sekunder. Literatur primer dikhususkan untuk karya-karya gramatika ulama mazhab Kufah seperti Ma'ānī al-Qur'ān karya al-Farrā', dan karya gramatika klasik yang membahas perselisihan mazhab Bashrah dan Kufah seperti al-Inshäf fi Masāìli al-Khilāf baina an-Nachwiyyīn al-Bashriyyīn wa al-Küfiyyīn. Sedangkan literatur sekunder mencakup sejumlah literartur klasik dan kontemporer yang mengkaji mazhab-mazhab gramatika Arab secara umum, dan secara khusus mazhab Kufah, juga sejumlah hasil penelitian disertasi yang meninvestigasi sejumlah tema gramatika dalam perspektif mazhab Kufah. Data dan informasi yang ditemukan dalam masing-masing literatur kemudian dicatat, diatur dan ditulis kembali dalam sebuah konsep penelitian.

\section{Pembahasan \\ a. Terminologi Isytiqāq}

Terminologi isytiqa a dalam khazanah literatur gramatika Arab klasik dimaknai secara berbeda oleh beberapa pakar 
gramatika. Bahkan, beberapa karya klasik yang mengusung judul isytiqāq pun dirasa gagal menyajikan satu pengertian yang jelas tentang terminologi isytiqāq seperti karya al-Ashma‘'̄ (215 H./ 830 M.) dan karya Ibnu Duraid (321 H./ 933 M.). Penelusuran seacara kronologis penggunaan terminologi ini dalam literatur bahasa seperti kamus-kamus, literatur gramatika dan secara khusus karya-karya linguis yang mengusung judul isytiq $\bar{a} q$ belum dapat memberikan kesimpulan kapan secara persis terminologi tersebut digunakan pertama kali, dan juga cara bagaimana makna bahasa kata tersebut beralih menjadi makna istilah yang diartikan sebagai bentuk pembentukan kata.

Thirzī (2005: 300) menyebut pemaknaan terminologi ini bermula dari konsep pembentukan kata dari kata yang lain tanpa penyebutan adanya relasi di antara kedua kata tersebut. Kemudian pakar gramatika melakukan pengembangan konsep dengan menambahkan adanya relasi bentuk dan makna yang dimiliki kedua kata, yaitu musytaq (kata bentukan) dan musytaq minhu (kata asal). Konsep isytiqāq kemudian berkembang jauh di tangan ahli linguistik Arab sehingga pemaknaannya mencakup apa yang disebut dengan alqalbu al-lughawī, yaitu pembentukan kata dari kata lain dengan merekonstruksi urutan huruf tertentu tanpa ada tambahan atau pengurangan huruf dengan ketentuan kedua kata tersebut secara makna memiliki kesamaan seperti antara kata /jadzaba/ (جَذَبَ) dan /jabadza/ (جَبَ) yang sama-sama bermakna menarik. (Al-Asmar, 1993: 336). Selain al-qalbu al-lughawī, konsep isytiqāq juga mencakup al-ibdāl allughawi yaitu pembentukan kata dari kata yang lain dengan proses substitusi salah satu huruf seperti antara kata /qadhama/ (قَضَ) yang berarti makan benda kering dan /khadhama/ (خَضَ) yang berarti makan benda basah. (Al-Asmar, 1993: 21). Selanjutnya ketiga konsep ini secara berurutan mewujud sebagai bentuk klasifikasi isytiqāq menjadi 1) istiqāq shaghīr , 2) isytiqāq kabīr , 3) isytiqāq akbar. Dari ketiga jenis ini, yang banyak digunakan adalah bentuk pertama sehingga jika disebut kata isytiqua maka secara langsung merujuk kepada jenis pertama ini.

Pengertian isytiq $\bar{a} q$ dalam prespektif mazhab Kufah juga mengalami perkembangan sebagaimana yang dijelaskan di atas. Melalui analisis penggunaan kata isytiqā $q$ dan turunannya dalam literatur mazhab Kufah ditemukan, bahwa istilah ini masih dimaknai secara sederhana sebagai proses pembentukan kata dari kata yang lain seperti pernyataan Al-Farrā' (1983: 1/125):

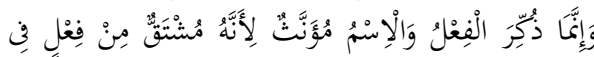<smiles>[Mg][Mg]C#[W]</smiles>

"Kata kerja menggunakan kata ganti laki-laki (mudzakkar) sedangkan subjek kata benda berjenis perempuan (mu'annats) sebab kata benda (mashdar) dibentuk dari kata kerja".

Pernyataan sejenis juga ditemukan dalam karya Al-Farrā' tersebut seperti dalam (1983: 2/44) dan (1983: 3/178).

Meskipun demikian, menurut penulis, pemahaman konsep isytiqa $q$ dalam benak ulama mazhab Kufah sudah berkembang melebihi apa yang mereka nyatakan dalam tulisan-tulisan seperti di atas. Setidaknya keberadaan relasi bentuk dan makna antara dua kata atau lebih yang mengalami proses derivasi (isytiqa $\bar{q} q$ ) sudah menjadi pemahaman bersama para pakar bahasa Arab. Adanya kesatuan makna atau kesamaan makna di antara kata-kata tersebut menjadi pertimbangan penting dalam proses derivasi. Tokoh seperti AlKhalīl bin Ahmad, Sibawaih, Al-Akhfasy, juga Al-Kisā' '̄, Al-Farrā' dan Tsa 'lab dari mazhab Kufah memiliki pemahaman sama tentang konsep isytiqāq sebagai proses pembentukan kata dari kata yang lain yang memiliki hubungan kesamaan makna dan kata.

Dalam perkembangan konsep berikutnya terdapat perbedaan definisi yang telah dikemukakan oleh pakar gramatika Arab. Beberapa konsep tersebut dicatat oleh Thirzi (2005: 23-24) sebagai berikut:

1. Dua kata yang memiliki kesamaan pada sebagian hurufnya, meski salah satunya lebih sedikit, keduanya merupakan hasil isytiqāq (derivatif). Pendapat ini diriwayatkan dari az-Zajjāj. 
2. Menurut Ar-Rumman̄̄ isytiqāq adalah: pemungutan kata cabang dari kata asal yang huruf-hurufnya terkandung dalam setiap pembentukan kata isytiqāq.

3. Ibnu az-Zamalkānī: Kata-kata yang terhimpun atau lahir dari satu kata asal dan memiliki kesamaan makna dasar.

4. Ar-Radhī al-Astarābādzī: Dua kata yang salah satuya diambil dari yang lain, atau berasal dari satu kata dasar.

5. Asy-Syarîf al-Jurjānī: Menciptakan satu kata dari kata yang lain dengan ketentuan adanya hubungan makna dan bentuk tapi beda pola kata.

Dari sejumlah definisi di atas dapat disimpulkan isytiqāq mencakup dua unsur, yaitu kata asal (radikal) yang mengalami proses pembentukan derivatif dan kata jadian sebagai hasil proses derivatif. Unsur pertama disebut sebagai al-musytaq minhu dan kedua sebagai al-musytaq. Kedua kata tersebut memiliki kesamaan dalam hal makna dan sejumlah huruf yang merangkainya.

\section{b. Radikal dan Turunan dalam Perspektif Mazhab Kufah}

Terkait persoalan penentuan kata radikal (ashlun / musytaq minhu) dalam proses derivasi, mazhab Kufah memiliki pandangan kontras dengan mazhab senior, mazhab Bashrah. Al-Anbārī dalam AlInshāf (2002: 192) menjelaskan, mazhab Kufah berpandangan bahwa kata benda mashdar berasal dari kata kerja $\left(f i^{\prime} l\right)$, sedangkan mazhab Bashrah berpandangan sebaliknya. Artinya, mazhab Kufah berpandangan bahwa radikal dalam bahasa Arab adalah bentuk kata kerja yang kemudian melahirkan sejumlah kata turunan, sedangkan menurut mazhab Bashrah radikal adalah kata benda mashdar yang melahirkan sejumlah kata turunan termasuk kata kerja.

Dalam penjelasannya, Al-Anbārī (2002: 192-201) mengupas tuntas tentang argumentasi masing-masing mazhab. Untuk mazhab Bashrah, al-Anbārī mengemukakan sembilan argumentasi, dan untuk mazhab Kufah hanya disebutkan empat argumentasi. Kemudian di akhir perdebatan, al-Anbārī mendukung pendapat mazhab Bashrah dengan menjelaskan kelemahan-kelemahan argumentasi mazhab Kufah dan menunjukkan sisi kekuatan mazhab Bashrah. Dengan sikapnya ini, al-Anbāri termasuk salah satu dari sekian banyak pakar yang memilih pendapat mazhab Bashrah dalam persoalan ini. Pendapat Mazhab Bashrah ini lebih mendominasi daripada pendapat mazhab Kufah dalam khazanah gramatikal Arab klasik.

Merujuk sejumlah argumentasi mazhab Bashrah yang dikemukakan AlAnbārī, penulis menangkap secara jelas kecenderungan logika dan filsafat dalam berargumentasi seperti ungkapan "Mashdar menunjukkan waktu secara mutlak, sedangkan $f i^{\prime} l$ menunjukkan waktu tertentu. Sesuatu yang mutlak merupakan dasar bagi sesuatu yang tidak mutlak." (2002: 193) dan ungkapan "Mashdar adalah kata benda yang mandiri, tidak memerlukan adanya $f i$ ' $l$. Adapun fi' $l$ tidak mampu berdiri sendiri dan selamanya memerlukan kata benda. Sesuatu yang mandiri tentu lebih layak menjadi dasar daripada sesuatu yang menggantungkan kepada yang lain.” (2002: 194). Kecenderungan ini membawa persoalan linguistik masuk ke dalam ranah filsafat dan menjauhkan kaidah-kaidah bahasa dari fakta kebahasaannya sendiri. Sesuatu yang banyak disayangkan oleh pakar bahasa Arab kontemporer terhadap kajian gramatika Arab klasik.

Berbeda dengan mazhab Bashrah, argumentasi mazhab Kufah dipandang lebih realistis dan dekat dengan fakta kebahasaan, utamanya morfologi dan sintaksis. Mazhab Kufah berargumentasi, " $F i$ 'l adalah dasar karena mashdar secara morfologis mengikuti bentuk $f i$ ' $l$ dalam hal $m u$ 'tal (vokalisasi) atau sahih (non vokalisasi).” (Al-Anbārī, 2002: 192) Kecederungan ini ditengarai sebagai paradigma metodologis mazhab Kufah dalam menggali teori kebahasaan. Sesuatu yang menjadi keunggulan mazhab Kufah dan kedekatannya dengan metodologi deskriptif ilmu bahasa modern. (AlChammūz, 1997: 9)

Selain itu, dengan memanfaatkan teori perbandingan bahasa-bahasa Semit pendapat Kufah lebih unggul dan sesuai 
dengan kaidah bahasa Semit secara umum. Wolfenshon, Orientalis Jerman mengemukakan (1929: 14; Al-Afghān̄̄, 1994: 141), kata radikal dalam bahasabahasa Semit bermula dari kata kerja, bukan kata benda mashdar sebagaimana yang dinyatakan sejumlah pakar bahasa Arab. Pernyataan ini mengkonfirmasi keunggulan pendapat mazhab Kufah tersebut dan kedekatannya dengan karakter bahasa-bahasa Semit. Dengan demikian, berdasarkan kenyataan di atas dapat disimpulkan bahwa pendapat mazhab Kufah lebih unggul daripada mazhab Bashrah.

Sebelum beralih ke permasalahan lain, perlu dikemukakan di sini pendapat pakar bahasa Arab kontemporer tentang persoalan radikal dalam proses derivasi bahasa Arab. Dalam linguistik Arab kontemporer pendapat yang diyakini lebih sesuai dengan perkembangan ilmu bahasa kontemporer adalah bahwa radikal yang menjadi sumber proses derivasi dalam bahasa Arab merupakan unsur dasar konsonan trilateral yang secara substantif belum memberikan arti dan selalu ada dalam setiap bentuk turunan seperti konsonan dh-, r-, b-, (ض) (ض) yang melahirkan bentuk turunan kata kerja dharaba, kata benda dharbun, dhāribun, madhrūbun, madhrabun. Prinsip yang melandasi pendapat ini adalah sebuah bentuk kata tidak pantas menjadi dasar atau sumber bagi bentuk kata yang lain, akan tetapi materi dasar yang membentuk semua kata turunan yang ada itulah yang lebih tepat. Radikal yang berupa kumpulan konsonan ini adalah satuan abstrak yang belum memiliki bentuk bunyi dan tulisan, juga fungsi sintaksis sehingga tidak bisa dikatakan sebagai bentuk kata benda (ism), kata kerja $(f i$ 'l), atau partikel (charf). (Abd al-Maqshūd, 2006: 173-174)

\section{c. Afiksasi sebagai Proses Derivasi dalam Perspektif Mazhab Kufah}

Proses derivasi dimulai dari bentuk radikal yang mengalami perubahan dengan adanya imbuhan atau afiks. Dalam linguistik Arab kontemporer, afiksasi derivatif terjadi dengan dua cara (Abd alMaqshūd, 2006: 179):
1. Afiksasi vokal terhadap radikal. Cara ini dilakukan untuk kata kerja perfek trilateral $\left(f i{ }^{\prime} l m \bar{a} d h \bar{\imath}\right)$ dalam bentuk aktif atau pasif seperti dharaba dan dhuriba.

2. Afiksasi konsonan dan vokal. Cara ini digunakan untuk sejumlah kata derivatif yang lain seperti kata kerja imperfek (fi'l mudhāri') yadhribu, kata kerja imperatif $\left(f^{\prime} l l\right.$ amr) idhrib, dan sejumlah kata benda seperti dhāribun, dharbun, madhrūbun, madhrabun.

Akan tetapi, dalam perspektif Mazhab Kufah, juga mazhab-mazhab lain yang mewakili pemikiran linguistik Arab klasik, afikasisai hanya terjadi dengan huruf konsonan. Vokal yang dikenal dengan harakat dalam bahasa Arab tidak disebut sebagai bentuk afiksasi. Bahkan, keberadaan harakat ini tidak diakui atau tidak mendapatkan tempat dalam penulisan kosakata Arab sehingga tidak heran jika perhatian ahli bahasa Arab klasik hanya tertuju pada huruf konsonan dalam mengkaji persoalan struktur kata bahasa Arab.

Dari sejumlah huruf konsonan yang digunakan dalam bahasa Arab, hanya beberapa diantaranya saja yang digunakan sebagai afiksasi. Ahli gramatika Arab menyebutnya sebagai churūf az-ziyādah (afiks). Terdapat perbedaan antara mazhab Kufah dan Bashrah dalam menentukan afiks. Mazhab Bashrah sebagaimana yang banyak diikuti oleh ahli bahasa Arab klasik menyebut afiks hanya ada 10 huruf, yaitu: alif, ya, waw, hamzah, mim, nun, ta', ha', sin, lam yang terangkum dalam ungkapan سألتمونيها (sa'altumūnīhā). (Ibnu Jinni， 1954: I/98)

Sedangkan mazhab Kufah berpandangan bahwa afiks tidak hanya terbatas pada sepuluh huruf tersebut, akan tetapi mencakup juga huruf-huruf yang lain seperti huruf za' ketiga pada kata kerja zalzala (زلز) dan huruf shad kedua pada kata kerja sharshara (صرصر) (Ghannām, 1997: II/161).

Pendapat mazhab Kufah ini didasarkan atas teori yang mereka rumuskan bahwa struktur kata dalam bahasa Arab tidak kurang dari tiga huruf konsonan dan tidak lebih dari tiga huruf 
konsonan. Kata yang terdiri atas lebih dari tiga huruf maka kata tersebut melebihi struktur dasar atau akar kata bahasa Arab dan di dalamnya terdapat imbuhan. (AlMakhzūmī, 1955: 217; Al-Chammūz, 1997: 160)

Ar-Radhī (1982: I/47) menyatakan: "Pendapat Sibawaih (mazhab Bashrah) dan mayoritas ahli gramatika Arab menyatakan bahwa $\operatorname{ar}-r u b \bar{a} \mathfrak{l}$ (quadrilateral, yaitu kata yang terdiri atas empat huruf), dan alkhumāsī (quinqiliteral, yaitu kata benda yang terdiri dari lima huruf) adalah kategori tersendiri, bukan bentuk derivasi ats-stulātsī (trilateral, yaitu kata yangterdiri atas tiggga huruf). Sedangkan Al-Farrā' dan al-Kisā'̄ meyakini bahwa keduanya berasal dari ats-tsulātsī. AlFarrā' berpendapat, imbuhan pada arrubā' $\bar{l}$ terdapat pada huruf terakhir dan pada al-khumāsī terdapat pada dua huruf terakhir. Sedangkan Al-Kisā'̄î̀ berpandangan imbuhan pada $\operatorname{ar}-r u b \bar{a}$ ' $\vec{\imath}$ terdapat pada huruf sebelum terakhir".

Teori mazhab Kufah ini menegaskan bahwa akar kata bahasa Arab tidak lebih dari tiga huruf dasar konsonan, dan jika suatu kata terdiri dari empat atau lima huruf itu berarti ada huruf imbuhan selain tiga huruf dasar tersebut. Teori dapat dicontohkan dengan kata benda ja'far (جعف) dan safarjal (سفرجل). Kata ja'faru merupakan quadrilateral yang menurut pendapat al-Farrā' berasal dari kata trilateral ja'fun (جe) kemudian mendapatkan imbuhan huruf ra', sedangkan menurut al-Kisā'̄ berasal dari ja'run (جع) kemudian mendapat imbuhan huruf fa' sebelum akhir dan menjadi ja'farun. Adapun kata safarjalun menurut keduanya berasal dari kata safarun (سفر) dan mendapatkan imbuhan huruf jim dan lam dan menjadi safarjalun.

Dengan demikian, mazhab Kufah berpandangan bahwa afiks atau imbuhan dalam bahasa Arab tidak dibatasi hanya pada sepuluh huruf yang populer itu, melainkan mencakup semua huruf yang digunakan dalam bahasa Arab. Pandangan ini didukung oleh sejumlah ahli bahasa terutama ahli bahasa kontemporer. Chassān berpendapat (1990: 183), bentuk kata dalam bahasa Arab memiliki tiga konsonan dasar yang saling terkait dalam proses derivasi. Selain untuk proses derivasi, tiga konsonan dasar ini juga sebagai entri kata dalam kaidah leksikografi. Selain itu, berdasarkan kajian komparatif bahasa-bahasa Semit, yang bahasa Arab merupakan bagian dari rumpun Semit, ditemukan fakta bahwa kata dasar dalam bahasa-bahasa Semit terdiri dari tiga huruf konsonan dasar. (alMakhzūmī, 1955: 220)

\section{d. Kata Derivatif dan Pola bentuknya dalam Pandangan Mazhab Kufah}

Pembahasan kata derivatif menjadi pembahasan utama dalam persoalan derivasi. Kata derivatif adalah kata hasil pembentukan proses derivasi yang dalam bahasa Arab dikenal dengan istlah "musytaqqāt" (derivable words). Dalam perspektif mazhab Kufah, selain kata kerja perfek, semua bentuk merupakan termasuk bagian dari kata derivatif. Kata derivatif ini mencakup bentuk mashdar, ism al-fā' $i l$, shiyaghu al-mubālaghah, ash-shifah almusyabbihah, ism al-maf'ül, ism at-tafdhìl, ism az-zamān, ism al-makān, dan ism alalat. Masing-masing bentuk kata derivatif ini dalam kajian morfologi memiliki pola standar yang menjadi acuan setiap kata yang berafiliasi kepada masing-masing bentuk. Berikut adalah penjelasan rincinya.

\section{Mashdar (verbal noun).}

Mashdar adalah kata benda yang menunjukkan makna peristiwa atau situasi tanpa disertai kala. Makna yang diacu oleh mashdar biasanya bersifat abstrak seperti كتابة (kitābatun) "penulisan". Konstruksi mashdar untuk kata kerja trilateral (tsulāts $\bar{l}$ ) secara morfologi bersifat sima' $\bar{\imath}$, yakni tidak mengikuti kaidah pola standar (wazan) tertentu. Pembentukannya sepenuhnya ditentukan oleh riwayat atau bentuk kata yang didengar langsung dari orang Arab. Meskipun demikian, terdapat beberapa pola yang dapat digunakan acuan untuk pembentukan mashdar kata kerja trilateral berwazan fa'ala. Acuan ini adalah bentuk pola fa'lun untuk kata kerja trilateral wazan fa'ala yang transitif (muta'addī) dan bentuk 
pola fu'ūlun untuk yang intansitif, seperti nashrun dari kata kerja transitif nashara "menolong", dan wushūlun dari kata kerja instransitif washala "sampai".

Mazhab Kufah dalam hal ini sejalan dengan pendapat umum ahli gramatika Arab. Al-Farrā' mengomentari firman Allah SWT QS. Al-Baqarah: 286, עَ

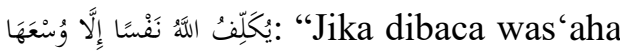
tentu boleh (secara qiyas), tetapi kami tidak pernah mendengar hal itu dari orang Arab". (Al-Farrā', 1983: I/188). Pernyataan di atas mengkonfirmasi bahwa pembentukan mashdar verba trilateral ditentukan pertama kali secara sima $\bar{\imath}$, dan ketika tidak ditemukan bentuk simā' $\bar{\imath}$ maka digunakan kaidah qiyas. Al-Farabī mengutip pendapat alFarrā': "Al-Farrā' berkata: Bentuk mashdar dari kata kerja berpola fa'alayaf'ulu dan fa'ala-yaf'ilu jika tidak ditemukan bentuk $\operatorname{sim} \bar{a} \mathfrak{\imath}$ maka bentuk mashdarnya mengikuti pola fa'lun atau fu'ūlun”. (Ghannām, 1997: 322)

Untuk mashdar kata kerja mazid (yakni yang mendapatkan imbuhan satu, dua, atau tiga huruf) pembentukannya berlaku secara qiyāsi mengikuti pola tertentu karena keberadaan kata kerja perfeknya yang satu macam.

\section{Ism al-fā il (active participle)}

Dalam mazhab Kufah istilah yang digunakan untuk menyebut ism al-fā'il

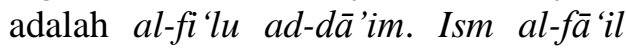
(active participle) adalah kata derivatif yang menunjukkan seseorang atau sesuatu yang menjalankan peristiwa seperti kata kātibun (كاتب) “orang yang menulis" hasil derivasi kata kerja kataba (كتب) yang menunjukkan makna seseorang yang melakukan perbuatan menulis. Ism al-fā'il dalam pembentukannya mengikuti pola baku yang sudah ditentukan oleh ahli gramatika Arab. Pembentukannya dari verba trilateral mengikuti pola fă'ilun (فاعل) baik kategori transitif atau intransitive seperti verba ghafara (غفر) menjadi ghāfirun (غافر), tāba (تاب) menjadi tā’ibun (تائب). Untuk verba intransitif, kadangkala pembentukannya mengikuti pola fa'ilun (فعل) seperti ta'ibun (تعب), pola fa'lān (نعلان) seperti 'athsyān (عطشان), af'alu (أنعل) seperti aswadu (أسود), fa'lun (فعل) (نعل) (نعل) seperti syahmun (شهم), atau fa'îlun (نعيل) seperti syarīfun (شريف). Adapun pembentukan Ism al-fā'il dari verba non trilateral menggunakan kaidah atau pola bentuk verba imperfek yang huruf pertamanya (charf mudhāra'ah) diganti oleh huruf mim seperti verba achsana - yuchsinu (أحسن يمسن) menjadi muchsinun (حسن), verba istaghfara - yastaghfiru ( استغفر) (يستغفر) menjadi mustaghfirun (مستغفر).

Pembentukan derivasi ism al-fā'il dalam perspektif mazhab Kufah tidaklah berbeda dengan apa yang sudah dinyatakan oleh ahli gramatika Arab lain di atas, yakni menganut prinsip qiyās, yakni mengikuti pola yang sudah baku. Bahkan, mazhab Kufah tidak mengakui bentuk $\operatorname{sim} \bar{a} \mathfrak{c}$ yang diriwayatkan dari orang Arab tetapi menyalahi pola yang sudah baku. Hal ini ditegaskan oleh Al-Farrā' (1983, II/153): "Sebagian kecil orang Arab mengatakan al-mutakabbar (المتكبر) untuk menggantikan kata al-mutakabbir (المتكبر) dengan berlandaskan verba yatakabaru (يتكبر). Bentuk kata yang nadir ini merupakan dialeg Al-Anshār yang tidak dapat digunakan sebagai pola standar". Pernytaan al-Farrā' ini mengkonfirmasi pendapat mazhab Kufah bahwa pembentukan derivatif ism al-fā'il sepenuhnya berdasarkan prinsip qiyās. Bentuk bahasa yang menyalahi prinsip ini tidak diakui dan keluar dari kaidah gramatika Arab.

\section{Shiyaghu al-mubālaghah}

Shiyaghu al-mubālaghah adalah bentukan dari ism al-fā'il untuk menunjukkan makna lebih atau banyak baik secara kuantitas ataupun kualitas. Bentuk ism al-fā'il seperti qā'imun (berdiri) menunjukkan sesorang yang melakukan perbuatan berdiri. Jika dikehendaki makna banyak, yakni 
banyak berdiri maka harus mengikuti pola shiyaghu al-mubālaghah, sehingga dapat dinyatakan bahwa bentuk ini berfungsu sebagai penguat atau penegas.

Shiyaghu al-mubālaghah memiliki sejumlah pola bentuk yang disepakati oleh ahli gramatika Arab, yaitu: fa" 'âlun (فَّال) seperti kata wahhābun (فومول) "banyak member”, fa'ūlun (ومّاب) seperti kata syakūrun (شكور) "banyak bersyukur", mif'ālun (مفعال) seperti kata midhyā'un (مضياع) "banyak menyianyiakan", fa'îlun (فعيل) seperti kata samī'un (سميع) "banyak mendengar", dan fa“ilun (نعل) seperti kata chadzirun (حذر) "banyak waspada".

Mazhab Kufah sejalan dengan apa yang menjadi rumusan ahli tata bahasa Arab di atas. Selain pola-pola bentuk di atas, mazhab Kufah juga menambahkan sejumlah pola bentuk lain yang tidak disebutkan oleh ahli gramatika Arab lain. Bentuk-bentuk itu adalah:

a. Pola fa'ulun (نعل). Pola ini didasarkan atas bacaan ayat Alسَيَعْلَمُونَ غَلًَا مَنِ انْخَذَابُ الْنَشَرُ mengetahui siapakah sebenarnya orang yang amat pendusta dan sombong". Pada ayat ini kata al-asyur dibaca dengan harakat dhammah pada huruf syin, bukan kasrah sebagaimana bacaan yang populer. Menurut mazhab Kufah, kata ini juga menunjukkan makna melebihkan. Al-Farrā' mengatakan sebagaimana yang dikutip Al-Anbārī dalam $A z$ Zāhir (1987: I/479): "Mujāhid membaca ayat ini (QS. 54: 26) dengan bacaan al-asyur, huruf syin didhammah. Alasannya mereka menghendaki makna melebih-lebihkan dalam mencela, yakni teramat sombong". Berdasarkan bacaan ini, Al-Farrā' menambahkan pola fa'ulun untuk kategori shiyaghu al-mubālaghah.

b. Fu'ālun dan fu' ‘ālun (نعال ، فنّال).

Al-Farrā' menambahkan dua pola ini berdasarkan bacaan ayat Al-Quran (QS. 38:5) lasyai'un 'ujābun atau 'ujjābun "suatu hal " لشيء عجاب / عجّاب) " لشاب) " yang sangat mengherankan". Al-Farrā' menjelaskan (1983: II/398): “Ayat lasyai'un "ujābun dibaca oleh Abu Abd ar-Rachmān as-Sullamī dengan lasyai'un 'ujjābun. Orang Arab mengatakan hādzā rajulun karīmun wa kurrāmun wa kurāmun (هذا رجل كريع وكّرام وكرام) “ini lelaku yang dermawan" maknanya adalah satu. Sebagaimana ayat (QS. 71: 22) wamakarū makran kubbāran (ومكروا مكرا كبارا) "dan mereka melakukan tipu daya yang amat besar". Kata kubbāran berarti melebih-lebihkan.

\section{Ash-shifah al-musyabbihah}

Ash-shifah al-musyabbihah adalah kata benda bentuk derivasi kata kerja trilateral jenis intransitif untuk menunjukkan makna seseorang atau sesuatu yang menyandang makna kata kerja tersebut secara berkelanjutan seperti kata chasanun (حسن) adalah ashshifah al-musyabbihah hasil derivasi kata kerja chasuna (حسن) "baik". Kata derivatif ini memiliki sejumlah pola bentuk yang sudah dirumuskan oleh ahli gramatika Arab, yaitu:

a. Jika berasal dari verba trilateral pola fa'ala maka memiliki pola bentuk fa'alun seperti qalaqun (قلق) "cemas", pola af'alu seperti aswadu (أسود) "hitam", pola fa "lānu seperti rayyānu (ريان) "segar".

b. Jika berasal dari verba trilateral pola fa'ula maka memiliki pola bentuk fa'îlun seperti 'azhīmun (عظيم) "besar", fa'lun seperti syahmun (شهم) “cerdas", fu'ālun 
seperti humāmun (هم) (ه)

"pemberani”, fa'ālun seperti jabānun (جبان) "penakut", fa'alun seperti bathalun (بطل) "pahlawan", fu'lun seperti chulwun (حلو) "manis".

Mazhab Kufah menambahkan pola bentuk lain untuk ash-shifah almusyabbihah yaitu pola fu'alatun. AlFarrā' menjelaskannya saat mengomentari kata al-jumu'ah (الجمعة) pada ayat Al-Quran (QS. 62:9): "Kata tersebut memiliki bacaan lain yaitu juma'ah, dialek Bani 'Aqīl. Dan jika dibaca demikian pun dibenarkan. Dengan demikian, maknanya adalah sifat hari, yakni hari yang mengumpulkan. Seperti ucapan rajulun dhuchakatun (ضحكة) yakni banyak tertawa."

\section{Ism al-maf' $\bar{u} l$}

Ism al-maf' $\bar{u}$ (passive participle) adalah kata derivatif berasal dari verba pasif yang menunjukkan seseorang atau sesuatu yang dikenai perbuatan seperti kata maktūbun (مكتوب) "yang ditulis" merupakan derivasi verba pasif kutiba (كتب) “ditulis". Ism al-maf'ūl ini pembentukan derivatifnya bersifat qiyāsi yakni mengikuti pola standar yang telah ditetapkan. Dalam hal ini tidak ada perbedaan antara mazhab Bashrah dan mazhab Kufah. Mereka sepakat, jika ism al-maf'ūl berasal dari verba trilateral maka mengikuti pola maf'ūlun (مغعول). Sedangkan jika berasal dari selain verba tiriliteral maka mengikuti pola verba imperfeknya dengan mengganti huruf pertama dengan huruf mim, dan mengganti harakat huruf sebelum terakhir dengan harakat fatah.

Akan tetapi terdapat peselisihan antara kedua mazhab tersebut dalam hal bentuk ism al-maf' $\bar{u} l$ yang berasal dari verba kategori ajwaf waw (verba trilateral yang huruf keduanya berupa huruf 'illat) seperti kata mashūghun (مصوغ ) yang berasal dari verba shaāgha yashūghu (صاغ - يصوغ). Sibawaih dan juga mazhab Bashrah tidak memperbolehkan bentuk ini digunakan secara apa adanya, tidak mengalami proses perubahan huruf 'illat (vokalisasi). Lebih jelas, Sibawaih menjelaskan bahwa kata seperti mashūghun tidak bisa digunakan bentuk langsungnya yaitu mashwūghun (مصووغ) yang mengikuti pola maf'ūlun (مفعول), akan tetapi harus mengalami perubahan bentuk karena adanya huruf 'illat. Pendapat ini diikuti juga oleh Al-Farrā' dari mazhab Kufah. Akan tetapi, AlKisā'̄ dari mazhab Kufah berpandangan lain. Dia memperbolehkan kata seperti mashūghun digunakan dengan bentuk asalnya yaitu mashwūghun. Bentuk asal ini dapat digunakan secara qiyāsī, yakni semua ism al-maf' $\bar{u} l$ yang terbentuk dari verba ajwaf waw dapat digunakan dalam bentuk asalnya. Ar-Rādhī (III/150) menjelaskan: “Al-Kisā'‘̄ meriwayatkan ungkapan khātamunu mashwūngun (خاتم مصووغ), kemudian dia memberlakukan bentuk ini secara qiyāsi untuk semua bentuk kata yang sejenis". Pendapat Al-Kisā'̄ ini meskipun menyalahi pendapat sebagian besar ahli gramatika Arab memiliki bukti kebahasaan yang bisa dibilang kuat. beberapa ungkapan sejenis yang diriwayatkan dari orang Arab adalah kata madwūfun (مدووف), maqwūdun (مقود), ma'wūdun (معود), dan mashwūnun (مصوون). (Ghannām, 1997: II/356) Sehinga pendapat ini bisa digunakan sebagai alternatif penggunaan ism al-maf' $\bar{u} l$ jenis ajwaf waw.

\section{Ism at-tafdhīl}

Ism at-tafdhīl adalah bentuk derivatif mengikuti pola af'alu untuk jenis maskulin dan pola fu'lā untuk jenis feminism untuk menjelaskan dua hal yang memiliki sifat sama tetapi salah satunya melebihi yang lain seperti kata akbaru (أكبر) "lebih besar" untuk jenis maskulin dan kubrā (كبرى) untuk jenis feminim. 
Beberapa persoalan ism at-tafdhìl yang dianut oleh mazhab Kufah dan berbeda dengan mazhab yang lain adalah persoalan pembentukan ism attafdhīl untuk warna. Menurut mazhab Bashrah pembentukannya tidak bisa dilakukan secara langsung mengikuti pola af'alu, melainkan melalui kata asyaddu (أشد) atau aktsaru (أكثر) dan diikuti oleh bentuk mashdar verba yang menunjukkan makna warna sebagai penjelas seperti asyaddu sawādan ( أشد (سوادا (lebih hitam". Alasannya menurut mazhab Bashrah sebab verba yang menunjukkan makna warna bukanlah verba trilateral, melainkan verba imbuhan dua huruf seperti iswadda (اسود) yang berpola if'alla (انعل). Mazhab Kufah berpandangan lain, pembentukan ism at-tafdhīl dari verba yang menunjukan makna warna bisa secara langsung tetapi hanya dibatasi dua warna yaitu hitam dan putih. Alasan logikanya, sebab keduanya warna dasar atau asal. Secara naqlī juga terdapat riwayat ungkapan yang didengar dari orang Arab seperti aswadu min chalaki al-ghurāb (اسود من حلك الغراب) "lebih hitam dari hitamnya burung gagak" dan ungkapan abyadhu min ukhti Banī Ibādh (أبيض من أخت بنى إباض) "lebih putih daripada Bani Ibādh". (AL-Anbārī, 2002: 125)

\section{8. Ism az-zamān dan ism al-makān}

Ism az-zamān adalah kata derivatif yang menunjukkan waktu terjadinya peristiwa seperti kata maulidun (مولد) "waktu lahir", sedangkan ism al-makān adalah kata derivatif yang menunjukkan tempat terjadinya peristiwa seperti kata mahbithun (مهبط) "tempat turun". Pembentukan dua jenis kata ini berlaku secara qiyāsi $\bar{l}$ yaitu dengan mengikuti ketentuan pola yang berlaku. Jika kata itu berasal dari verba trilateral jenis shahih (hurufnya tidak ada yang berupa huruf 'illat) maka mengikuti pola maf'ilun (مفعل) jika verba imperfeknya huruf kedua berharakat kasrah seperti jalasa - yajlisu (جلس يجل) pembentukan ism az-zamān dan ism al-makān adalah majlisun (بلسي), dan mengikuti pola maf'alun (مغَ) jika huruf kedua berharakat fatah atau dhammah seperti kataba - yaktubu (كتب بكتب) (كتب) $\rightarrow$ maktabun (مكتب) dan amina - ya'manu (أمن يأمن) ma'manun (مأمن). Dan jika kata itu berasal dari verba trilateral jenis mu'tall (salah satu hurufnya berupa huruf 'illat) maka mengikuti pola maf'ilun untuk mu'tall $f a$ ' (huruf pertama berupa huruf 'illat) seperti waqafa yaqifu (وقف يقف) C mauqifun (موقف), dan pola maf'alun untuk mu'tal lam (huruf ketiga berupa huruf 'illat) seperti jarā yajrī (جرى يجري) $\rightarrow$ majran (جرئ).

Dalam persoalan ini, mazhab Kufah sepakat dengan apa yang dinyatakan oleh ahli gramatika Arab yang lain. Perbedaan yang muncul adalah, mazhab Kufah memperbolehkan verba non trilateral menggunakan pola maf'alun

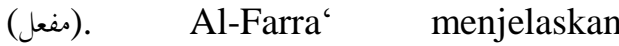
pendapatnya ini ketika menafsirkan

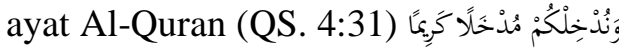
"Dan Kami masukkan kamu ke tempat yang mulia". Al-Farrā' mengatakan: "Kata mudkhalan dan madkhalan sama."

\section{Ism al-ālat}

Ism al-ālat adalah kata derivatif berasal dari verba trilateral jenis transitif untuk menunjukkan sarana atau alat suatu perbuatan. Pembentukan kata ini dilakukan secara qiyāsī dengan mengikuti pola-pola yang sudah ditentukan yaitu: 1) mif"ālun (مفع) seperti miftāchun (مفتح) "kunci", minsyārun (منشار) "gergaji”. 2) mif"alun (مغعل) seperti misyrathun (مشرط) "pisau bedah", midfa'un (مدفع) "meriam". 3) mif'alatun (مغعلة) seperti mistharatun (مسطرة) (ملعقة) (penggaris", mil'aqatun "sendok".

Mazhab Kufah juga memberlakukan secara qiyāsi pola bentuk lain yaitu fi'ālun (نعال). Al-Farrā’ mengemukakan pendapatnya itu saat menjelaskan kata 
al-khiyāth (الخياط) pada ayat Al-Quran (QS. 7:40) chattā yalija al-jamalu fî

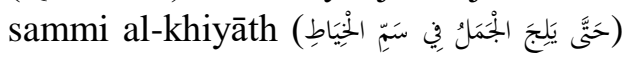
“...hingga unta masuk ke lubang jarum...": "Dikatakan pula al-khiyāth dan al-mikhyath, maksudnya jarum. Dalam qira'ah Abdullāh disebutkan almikhyath. Keduanya dapat dijadikan sebagai pola untuk kata yang lain seperti izār dan mi’zar (إزار مئز) “kain penutup badan", lichāf milchaf ( لحاف

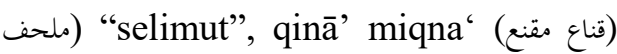
"kerudung", qirām miqram (قرام مقرم) "kain penutup tipis". (1983: I/379)

\section{Kesimpulan}

Mazhab Kufah merupakan mazhab linguistik Arab klasik yang banyak memberi konstribusi pemikiran linguistik. Gagasan dan metodologi pemikirannya dekat dengan aliran linguistik deskriptif yang menitikberatkan pada metodologi induktif dengan koleksi data lingual yang berasal dari sumber otentik dengan cakupan yang luas. Dalam persoalan derivasi, mazhab Kufah berpandangan verba $\left(f{ }^{\prime} l\right)$ sebagai radikal yang melahirkan sejumlah kata derivatif. Pandangan ini sesuai dengan temuan linguistik kontemporer bahasa Semit. Dalam hal afiksasi, Mazhab Kufah juga tidak membatasi afiks (churūf az-ziyādah) hanya pada sepuluh huruf sebagaimana yang ditentukan mazhab Bashrah, tetapi mencakup semua abjad Arab. Pendapat ini sesuai dengan fakta pembentukan kata bahasa Arab, dan mendukung teori gramatika Arab kontemporer bahwa kata akar dasar bahasa Arab tidak kurang dan tidak lebih dari tiga huruf. Pembentukan kata derivatif dalam perspektif mazhab Kufah memiliki bentuk yang lebih beragam dengan penggunaan prinsip qiyās yang lebih luas dari mazhab Bashrah. Hal ini tidak lain karena cakupan data kebahasaan yang digunakan lebih luas dari mazhab Bashrah.

Penelitian tentang mazhab Kufah dan kontribusinya dalam perspektif linguistik kontemporer menjadi tema yang sangat menarik. Penelitian ini hanya mengkaji dari satu sisi yaitu morfologi dengan tema derivasi. Tema selain derivasi dan atau tema di luar morfologi seperti fonologi, sintaksis dan semantik dapat menjadi objek kajian penelitian selanjutnya.

\section{Daftar Pustaka}

Abd al-Maqshūd, Muchammad Abd alMaqshūd. 2006. Dirāsatu al-Binyah ash-Sharfiyyah fi Dhau'i alLisāniyyāt al-Washfiyyah. Beirut: Ad-Dār al-'Arabiyyah li alMausū'āt.

Al-Afghāni, Sa‘īd. 1994. F̄̄ Ushūli anNachwi. Damaskus: Mudīiriyyatu alKutub wa al-Mathbū'āt alJāmi‘iyyah.

Al-Anbārī, Abu Bakar Muchammad bin alQāsim. Editor Chātim Shālich adhDhāmin. 1987. Az-Zāhir fị Ma‘āni Kalāmi an-Nās. Baghdad: Dār asySyu'ūn ats-Tsaqāfiyyah al-'Ammah.

Al-Anbārī, Abu al-Barakāt. Editor Jūdah Mabrūk. 2002. Al-Inshāf fì Masā'ili al-Khilāf baina al-Bashriyyīn wa alKüfiyyinn. Kairo: Maktabah alKhanjī.

Al-Asmar, Rājī. 1993. Al-Mu'jam alMufashshal fi 'Ilmi ash-Sharfi. Beirut: Dār al-Kutub al-'Ilmiyyah.

Al-Chammūz, Abd al-Fattāch. 1997. AlKüfiyyūn fì an-Nachwi wa ashSharfi wa al-Manhaj al-Washfi alMu'āshir. Amman: Dār 'Ammār.

Al-Fadhlī, Abd al-Hādī. 1986. Marākiz adDirāsāt an-Nachwiyyah. Yordania: Maktabah al-Manār.

Al-Farrā', Yachyā bin Ziyād. 1983. Ma 'ān̄̄ al-Qur'ān. Beirut: 'Alamu al-Kutub.

Al-Khuli, Muhammad Ali. 1982. A Dictionary of Theoritical Linguistic. Beirut: Labrarie Du Liban.

Al-Makhzūmī, Mahdī. 1955. Madrasatu al-Küfah wa Manhajuhā fì Dirāsati al-Lughah wa an-Nachwi. Baghdad: Mathba'ah Dār al-Ma'rifah.

Arifin, Zaenal. 2009. Morfologi Bentuk, Makna, dan Fungsi. Jakarta: PT Grasindo.

Ar-Rādhī, Muchammad bin Chasan AlIstirābādzī. Editor Muchammad Nūr al-Chasan, Muchammad az-Zafzāf, Muchammad Muchyiddīn Abd alChamīd. 1982. Syarchu Syāfiyati ibni al-Chājib. Beirut: Dār al-Kutub al-'Ilmiyyah. 
Ath-Thawīl, As-Sayyid Rizq. 1984. AlKhilāf baina an-Nachwiyyīn Dirāsah wa Tachlīl wa Taqwīm. Mekkah al-Mukarramah: alMaktabah al-Faishaliyyah.

Baalbaki, Ramzi Munir. 1990. Dictionary of Linguistic Terms. Beirut: Dar elIlmi Malyin.

Chassān, Tammām. 1990. Manāhiju alBachtsi fi al-Lughah. Kairo: Maktabah al-Anjilū al-Mishriyyah.

Dhaif, Syauqī. 1992. Al-Madāris anNachwiyyah. Kairo: Dār al-Ma'ārif.

Ibnu Duraid, Muchammad bin Chasan. Editor Abd as-Salām Muchammad Hārūn. 1991. Al-Isytiqāq. Beirut: Dār al-Jail.

Ibnu Jinnī, Utsmān. Editor Ibrāhām Musthafā Abdullāh Amīn. 1954. AlMunshif Syarchu at-Tashrïf. Kairo: Wizāratu al-Ma'ārif al'Umūmiyyah.

Ghannām, Mu'min bin Shabrī. 1997. Manhaju al-Küfiyyīn fi ash-Sharfi. Mekkah al-Mukarramah: Jāmi'atu Ummi al-Qurā.

Kridalaksana, Harimurti. 2009. Kamus Linguistik. Jakarta: PT Gramedia.

Thirzī, Fu'ād Channā. 2005. Al-Isytiqāq. Beirut: Maktabah Lubnān Nāsyirūn.

Wolfenshon, Israel. 1929. Tārīkhu alLughāt as-Sāmiyah. Kairo: Lajnah at-Ta'liff wa at-Tarjamah wa anNasyr. 